\title{
Characterization of Bacillus spp. from the rhizosphere of potato Granola varietiy as an antibacterial against Ralstonia solanacearum
}

\author{
NUR PRIHATININGSIH ${ }^{1, \bullet}$, TRIWIDODO ARWIYANTO ${ }^{2}$, BAMBANG HADISUTRISNO ${ }^{2}$, JAKA WIDADA ${ }^{2}$ \\ ${ }^{1}$ Faculty of Agriculture, Universitas Jenderal Soedirman. J1. Dr. Suparno, Purwokerto Utara, Banyumas 53123, Central Java, Indonesia. \\ Tel./fax.: +62-281-638791, `email: prihatiningsihnur@gmail.com \\ ${ }^{2}$ Faculty of Agriculture, Universitas Gadjah Mada. Jl. Flora No. 1, Bulaksumur, Sleman 55281, Yogyakarta, Indonesia
}

Manuscript received: 14 June 2020. Revision accepted: 20 August 2020.

\begin{abstract}
Prihatiningsih N, Arwiyanto T, Hadisutrisno B, Widada J. 2020. Characterization of Bacillus spp. from the rhizosphere of potato Granola variety as an antibacterial against Ralstonia solanacearum. Biodiversitas 21: 4199-4204. Ralstonia solanacearum is one of the important wilt pathogens that significantly decreased potato yields in Indonesia. One of the strategies to control wilt disease is the use of Bacillus sp. that isolated from potato rhizosphere. Bacillus sp. is an antagonist against some phytopathogenic fungi and bacteria. The objectives of the study were to identify 5 strains of Bacillus spp. (B46, B209, B211, B298, and B315) that is capable of suppressing the growth of $R$. solanacearum. Experimental assays were performed to determine the growth inhibition of $R$. solanacearum by culturing in a two-layer medium. The identification of Bacillus spp. was performed based on physiological and biochemical characters and molecular identification. Results showed that all of Bacillus spp. are capable of suppressing the growth of $R$. solanacearum. B. subtilis B315 isolate was the most effective biocontrol agent in inhibiting $R$. solanacearum growth by a bacteriostatic mechanism. All Bacillus spp. have similarities in physiological and biochemical characters. Based on the molecular analysis, Bacillus sp. B46, B209, B211, and B298 were homologous to B. subtilis subspecies spizizeni RRLKE2, whereas Bacillus sp. B315 was homologous to B. subtilis strain WIFD5.
\end{abstract}

Keywords: Antibacterial, Bacillus, potato, Ralstonia solanacearum, rhizosphere

\section{INTRODUCTION}

The extensive use of chemical pesticides has long been known to pose environmental problems leading to detrimental effects on human health. Biological control using microorganisms to suppress plant pathogens offers a potential alternative to synthetic chemicals. Biocontrol agents are preferable options as they provide more beneficial characteristics such as high specificity against the targeted plant pathogens, strong degradability after practical usage, and low mass-production costs. Biological control has inherent characteristics, i.e. being healthier for agricultural workers and people living in agrarian communities, no waiting period after the release agents, and no phytotoxic damage to plants. Furthermore, applications with biological agents can reduce and replace synthetic pesticides with a more sustainable method of pest management (Lenteren et al. 2018).

Potato cultivation in Indonesia currently faces three main problems, i.e. seed quality, cultivation techniques, and the emergence of pests and diseases. One of the major diseases in potato plants is bacterial wilt caused by Ralstonia solanacearum race 3 biovar 2 (Yabuuchi et al. .1995) previously known as Pseudomonas solanacearum E.F. Smith (Fahy and Hayward 1983). R. solanacearum is considered as one of the most destructive bacterial pathogens in potato plants because it can induce rapid and fatal wilting symptoms and a considerable yield loss. Bacterial wilt has spread to all potato growing areas, affecting over $70 \%$ of potato farming and causing yield losses of between 50 to 100\% (Muthoni et al. 2012).

The application of beneficial microorganisms such as Bacillus spp. could reduce disease, enhance plant growth and crop yields. Bacillus spp. has been known can control various fungal and bacterial plant pathogens. Some of the plant pathogens such as pathogenic fungi Fusarium sp. and Verticillium sp. are causes of wilting in important plants such as bananas, tomatoes, and cotton. Alternaria sp. causes leaf spot diseases on tomatoes, potatoes, cabbage, and leaf onions. Rhizoctonia solani, Pythium sp. and Sclerotium sp. cause of damping-off and foot rot diseases, powdery mildew and downy mildew on vegetables, cotton, grape, ornamental plants, and beans (Sharma and Kaur 2010). A previous study showed that about $68 \%$ of $B$. subtilis strains isolated from potato rhizosphere were able to reduce the growth of Rhizoctonia solani and $91 \%$ against Fusarium solani with inhibition rates ranging from 69-91\% and 56-86\% respectively (Calvo et al. 2010). Indigenous Bacillus spp consortia could control anthracnose by Colletotrichum capsici and enhance the growth of chili plants (Yanti et al. 2020). Bacillus amyloliquefaciens can reduce the incidence of bacterial wilt in tomatoes, suppress the $R$. solanacearum population, and improve the overall growth of tomato plants (Singh et al. 2016).

Results of previous studies showed that Bacillus spp. isolated from the rhizosphere of potato Granola variety are potential as biocontrol agents against pathogenic wilt bacteria of $R$. solanacearum and could enhance the tomato 
plant resistance (Prihatiningsih et al. 2006; 2011). Therefore, the research aimed to characterize Bacillus spp. From the rhizosphere of potato Granola variety based on physiological, biochemical, and molecular approaches and evaluate their capability in suppressing the growth of $R$. solanacearum that would give a better understanding of the potential of these bacterial strains.

\section{MATERIALS AND METHODS}

\section{Microorganisms and cultures}

Five strains of Bacillus spp. (B46, B209, B211, B298, and B315) were isolated from the rhizosphere of potato Granola variety and previously selected (Prihatiningsih et al. 2006). The isolates were obtained from healthy potato plants in the bacterial wilt endemic area in Serang Village, Purbalingga Regency, Indonesia, located at an altitude of 1,200 m above sea level. The TSA (Tryptic Soy Agar) medium was used for bacteria isolation. Preliminary assays included Gram reaction test, catalase test, colony morphological identification, and endospore form. The culture was cultivated by lyophilization and grown on the YPGA (Yeast Peptone Glucose Agar, containing 5, 10, 10, and $17 \mathrm{~g}$ respectively) medium at $28{ }^{\circ} \mathrm{C}$ for 48 hours. $R$. solanacearum isolated from the same field as those of Bacillus spp. was used as a challenge strain.

\section{Inhibition assay of Bacillus spp. against Ralstonia solanacearum}

Inhibition assay of Bacillus spp. against $R$. solanacearum was determined by a two-layer media method (Ghosh 2007; Singh et al. 2016). Briefly, one spot of each bacterial colony of $B$. subtilis was inoculated on YPGA media and incubated for $24 \mathrm{hr}$ at $28{ }^{\circ} \mathrm{C}$ (room temperature). The second layer was $4 \mathrm{~mL}$ of water contained $200 \mu \mathrm{l}$ of $R$. solanacearum suspension poured on the surface of the previous YPGA media. Then, add with a drop of chloroform. The plates were incubated at $28{ }^{\circ} \mathrm{C}$ for 2 days. Bacterial inhibitory activity was quantified by the presence of a clear zone on the surface of the growth medium.

\section{Physiological and biochemical characterization}

The physiological and biochemical characterization was performed through several assays, including the utilization of carbon and nitrogen compounds (Slepecky and Hemphill 2006; Abusham et al. 2009). All isolates were assayed for their ability in utilizing several carbon compounds (arabinose, xylose, dextrose, cellobiose, maltose, mannitol, sorbitol) as a carbon source that indicated by a color change of the medium from green to yellow. The color change of medium indicated the ability of these isolates to use citric acid as a carbon source and the presence of alkaline properties to blue. Gram reaction, tests of oxidase, catalase, and levan formation of the bacteria were also conducted. The growth of isolates was evaluated at different incubation temperatures and various $\mathrm{pH}$ of the media, salt $(\mathrm{NaCl})$ tolerant, enzyme activity, motility, and anaerobic growth tests. The physiological and biochemical characterization of Bacillus spp. were carried out as follows:

Nitrate reduction test was conducted by inoculating the bacteria in the nitrate broth medium. The Follet and Ratcliff's reagent was added to the medium after 48 hours of incubation. A color change indicated the presence of nitrite to red or orange-brown.

Starch hydrolysis tests were carried out by culturing bacteria on a starch medium and incubated at $28^{\circ} \mathrm{C}$ for 48 hours. After incubation, the medium was added with the KI solution (Lelliot and Stead 1987; Chun and Vidaver 2001). A clear zone showed the capability of bacteria to hydrolyze starch.

The growing test was conducted on the Yeast Pepton (YP) broth medium, incubated at $4{ }^{\circ} \mathrm{C}$ and $45^{\circ} \mathrm{C}$. Bacillus spp. were grown on $C D$ (casein dextrose) broth medium with a pH of 5.7 (Chun and Vidaver 2001). This assay was conducted to determine the ability of bacteria to grow on various temperatures and $\mathrm{pH}$. Turbid media indicated bacterial growth.

Salt tolerance test was performed by growing bacterial isolates on the YP broth medium containing $0,1,3,5$, and $7 \% \mathrm{NaCl}$ respectively. Unclear/turbid media indicated bacterial growth.

A motility test was carried out by culturing five isolates of Bacillus sp. in the Edwards and Brunner media and observed daily. Motile bacteria indicated by diffuse and hazy growth spread throughout semi-solid media.

The oxidativelfermentation glucose test was carried out to determine the ability of bacteria to produce acid and capable of oxidizing and fermenting glucose. Acid production is formed through glucose metabolism by fermentation or oxidation that indicated by the color change of the medium from green to yellow.

The test of Voges Proskauer (VP) would indicate a positive reaction if the medium turned to milky white and light red.

The Bacillus spp. isolates were inoculated in $10 \mathrm{~mL}$ of glucose solutions in a test tube, then sealed with $1 \mathrm{~cm}$-thick sterile paraffin oil to test the growth in anaerobic conditions. The growth was observed at 3 and 7 days of incubation at the temperature of $\left\langle 45^{\circ} \mathrm{C}\right.$; and 1 and 3 days of incubation at $\geq 45^{\circ} \mathrm{C}$ (Chun and Vidaver 2001). Anaerobic bacteria were indicated by murky or unclear glucose solution.

The positive levan formation was indicated by a mucoid colony (Lelliot and Stead 1987; Sands 1990).

\section{Molecular characterization}

Five isolates of Bacillus spp. were subjected to molecular characterization. Molecular characterization was carried out by analyzing the 16S rRNA gene sequence for further confirmation of Bacillus spp. All of the sequences were then aligned by the Clustal W. method. The phylogenetic tree was generated using MEGA4 and BLAST programs to determine the homology among the species of Bacillus in the GenBank database (http://www.ncbi.nih.gov). 


\section{Data analysis}

Data were analyzed by descriptive methods and compared with the reference.

\section{RESULTS AND DISCUSSION}

\section{Growth inhibitory activity of Bacillus spp. against Ralstonia solanacearum}

Five isolates of Bacillus spp. (B46, B209, B211, B298, and B315) were capable of inhibiting the growth of R.solanacearum. Bacillus sp. B315 isolate exhibits the largest inhibition zone $(18 \mathrm{~mm})$ against $R$. solanacearum (Figure 1). B315 isolate inhibits the growth of $R$. solanacearum by bacteriostatic and antibiosis mechanisms. Growth inhibition of $R$. solanacearum on peptone broth medium inoculated with Bacillus indicated a bacteriostatic mechanism. Bacillus sp. B315 showed an antibiosis mechanism against $R$. solanacearum indicated by amylase secretion as secondary metabolites. Prihatiningsih and Djatmiko (2016) reported that amylase is one of the antagonist components. Some compounds could express nutrient competition in antagonist activity as a signal for pathogens to compete in achieving the plants (Kohl et al. 2019). Bacillus sp. strain GU 057 exhibits the largest zone of inhibition against Staphylococcus aureus $(18 \mathrm{~mm})$ followed by Microccos luteus $(13 \mathrm{~mm})$ after 48 hours of incubation (Amin et al. 2012). Endophytic Bacillus sp. from maize stem produces protease and lipase. It can suppress the growth of Rhizoctonia solani $>50 \%$ and have a strong antagonistic index against Pantoea sp. (> 4) (Mugiastuti et al. 2020).

\section{Physiological and biochemical characterization.}

The results of physiological and biochemical tests from five isolates of Bacillus spp. are shown in Table 1. All isolates showed a positive reaction to physiological and biochemical tests. Bacillus sp. isolates (B46, B209, B211, B298, and B315) were able to use citric acid as the carbon source indicated by bacterial growth in the citric acid medium (Chun and Vidaver 2001). The carbon source such as glucose was an essential nutrient for the growth and production of secondary metabolites, including antibiotics by antibiosis mechanism (Amin et al. 2012).

Five isolates of Bacillus spp. were also capable of reducing nitrate as shown by a color change to brownish red. The ability of Bacillus spp. to reduce nitrate is consistent with the findings from the previous study (Jamil et al. 2007). B. subtilis utilize nitrate as the electron acceptor in their metabolism.

The positive reaction of starch hydrolysis showed that Bacillus isolates were capable of producing a starchhydrolyzing enzyme (amylase). It is shown by the clear zone on the starch medium when added with a drop of KI solution. Previous studies (Pandey et al. 2000; Irfan et al. 2011; Khan and Priya 2011) showed that B. subtilis produced an extracellular enzyme, $\alpha$-amylase, an important enzyme involved in starch hydrolysis. This enzyme is required in food, fermentation, paper, and textile industries.

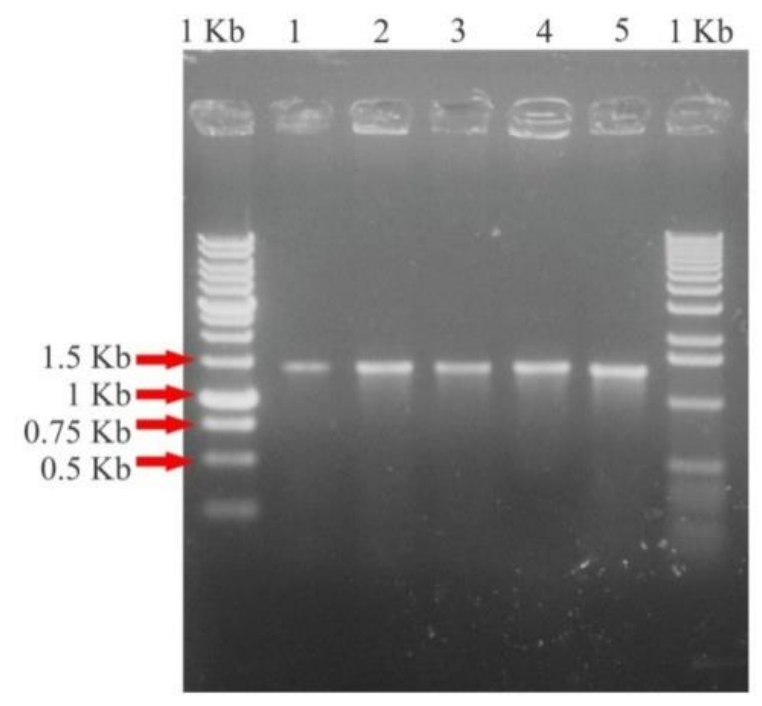

Figure 2. Agarose gel electrophoresis of PCR amplified product from five Bacillus spp. for 16S rRNA gene employing primers of $63 \mathrm{~F}$ and 1387R Notes: lane 1 and 7 were primers of $63 \mathrm{~F}$ and 1387R, lane 2: Bacillus sp. B46, lane 3: Bacillus sp. B209, lane 4: Bacillus sp. B211, lane 5: Bacillus sp. B298, lane 6: Bacillus sp. B315

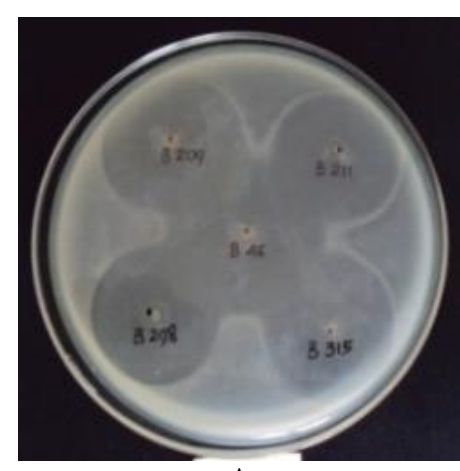

A

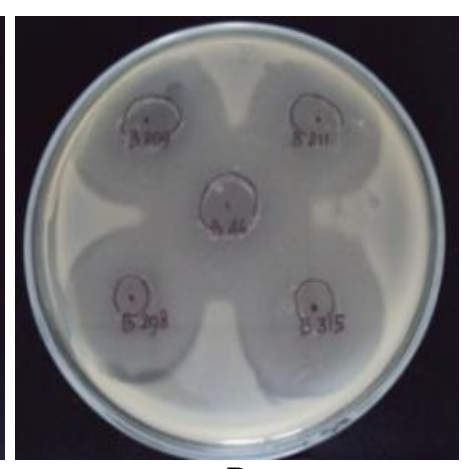

B

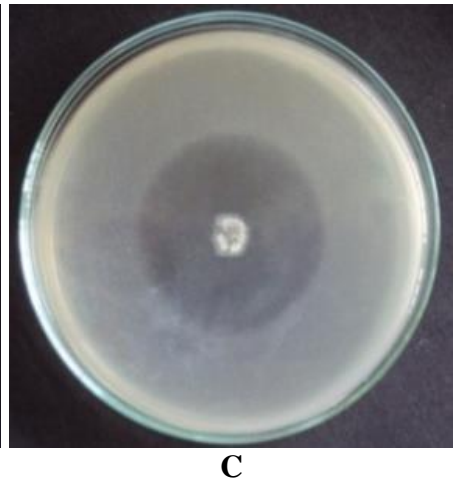

C

Figure 1. Growth inhibition of five Bacillus spp. isolates (A) with chloroform and (B) without chloroform, (C) Bacillus sp. B315 against Ralstonia solanacearum $(18 \mathrm{~mm})$ 
Table 1. The results of physiological and biochemical assays on five isolates of Bacillus spp.

\begin{tabular}{|c|c|c|c|c|c|c|c|c|}
\hline \multirow{2}{*}{ Physiological and biochemical characteristics } & \multicolumn{5}{|c|}{ Isolates } & \multirow{2}{*}{$\begin{array}{c}\text { B. subtilis } \\
\text { (Chun and } \\
\text { Vidaver 2001) } \\
\end{array}$} & \multirow{2}{*}{$\begin{array}{l}\text { B. subtilis } \\
\text { (Ashiru et } \\
\text { al. 2012) }\end{array}$} & \multirow{2}{*}{$\begin{array}{c}\text { B. subtilis } \\
\text { MH-4 (Jamil } \\
\text { et al. 2007) }\end{array}$} \\
\hline & B46 & B209 & B211 & B298 & B315 & & & \\
\hline \multicolumn{9}{|l|}{ Utilization and degradation of carbon compounds } \\
\hline Arabinose & nd & nd & nd & nd & nd & + & + & nd \\
\hline Xylose & nd & nd & nd & nd & nd & + & + & nd \\
\hline Dextrose & + & + & + & + & + & + & nd & nd \\
\hline Selobiose & + & + & + & + & + & nd & $\mathrm{L}$ & nd \\
\hline Maltose & + & + & + & + & + & nd & + & + \\
\hline Manitol & + & + & + & + & + & nd & + & + \\
\hline Sorbitol & + & + & + & + & + & nd & $\mathrm{L}$ & + \\
\hline Uses of citrate & + & + & + & + & + & + & + & + \\
\hline \multicolumn{9}{|l|}{ Changes of nitrogen compound } \\
\hline Nitrate reduction & + & + & + & + & + & nd & + & + \\
\hline \multicolumn{9}{|l|}{ Macromolecule changes } \\
\hline Starch hydrolysis & + & + & + & + & + & + & + & nd \\
\hline \multicolumn{9}{|l|}{ Other physiological and biochemical characteristics } \\
\hline Gram & + & + & + & + & + & + & + & nd \\
\hline Catalase & + & + & + & + & + & nd & + & nd \\
\hline Oxidase & + & + & + & + & + & nd & + & nd \\
\hline \multicolumn{9}{|l|}{ Oxidative } \\
\hline Fermentative $(\mathrm{O} / \mathrm{F})$ & + & + & + & + & + & nd & nd & nd \\
\hline Levan formation & nd & nd & nd & nd & + & nd & nd & nd \\
\hline Voges Proskauer test & + & + & + & + & + & + & - & nd \\
\hline Growth on $\mathrm{NaCl} 1,3,5,7 \%$ & + & + & + & + & + & + & nd & nd \\
\hline Growth at $45^{\circ} \mathrm{C}$ & + & + & + & + & + & + & nd & nd \\
\hline Growth at $\mathrm{pH} 5.7$ & + & + & + & + & + & + & nd & nd \\
\hline Motility & + & + & + & + & + & + & + & nd \\
\hline \multicolumn{9}{|l|}{ Spore position: } \\
\hline Terminal & - & - & - & - & - & - & nd & nd \\
\hline Central & + & + & + & + & + & + & nd & nd \\
\hline Subterminal & - & - & - & - & - & - & nd & nd \\
\hline
\end{tabular}

Note: +: positive reaction or presence of bacterial growth; -: negative reaction or no bacterial growth; L: weak reaction; nd: not determined

All isolates of Bacillus spp. in this study positively reacted to Gram reaction, catalase, and oxidase tests. The result of oxidative/fermentative $(\mathrm{O} / \mathrm{F})$ tests showed that all isolates showed a positive reaction after one day of incubation. Five isolates of Bacillus spp produce acid from glucose and change the acidic final product to be neutral. It is known as acetoin (acetyl methylcarbinol) or 2,3 butanediol; it produces red light in the medium (Fahy and Hayward 1983).

It showed that the Bacillus spp. isolates were able to grow on the medium containing $7 \%$ of $\mathrm{NaCl}$ after 4 days of incubation. Salt significantly influenced bacterial growth due to its effect on the osmotic pressure of the medium. Gram-negative bacteria grow in the high-salt environments accumulate glutamic acid and proline within their bacterial cells, while Gram-positive bacteria accumulate proline.

Bacillus spp. can grow at $45^{\circ} \mathrm{C}$ indicated by the muddiness of the liquid medium. These bacteria were classified as a mesophile or a thermophile (Goto 1992). The ability of Bacillus spp. to grow at a $\mathrm{pH}$ of 5.7 indicates that these bacteria are classified as acidophiles. Results of the motility test showed that the Bacillus spp. were able to move at the medium of Edward and Brunner after 6 and 11 days of incubation that indicated by the cloudiness of the medium after five days of incubation.

\section{Genetic variability of Bacillus sp.}

Genetic variability of five isolates of Bacillus sp. was determined by $16 \mathrm{~S}$ rRNA gene on gel electrophoresis. The five isolates of Bacillus spp. produced the same band of 1.5 $\mathrm{kb}$ (Figure 2).

The phylogenetic tree was constructed using the neighbor-joining algorithm method, with the bootstrap replication percentage reaching 1,000 times of resampling (Figure 3). Genetic variability of Bacillus sp. isolates was identified by comparing their $16 \mathrm{~S}$ rRNA gene sequence with the 16S rRNA gene sequence of different strains in the database. The results showed that Bacillus sp. B46, B209, B211, B298 were homologous with B. subtilis subspecies spizizeni RRLKE2 with a similarity of 22.1, 22.1, 47.3, and $47.3 \%$ respectively, while Bacillus sp. B315 was homologous with B. subtilis strain WIFD5 with $83.7 \%$ similarity. Database from the GenBank and result from the molecular analysis supported the finding that Bacillus sp. B315 was very closely related to Bacillus subtilis strain WIFD5. 


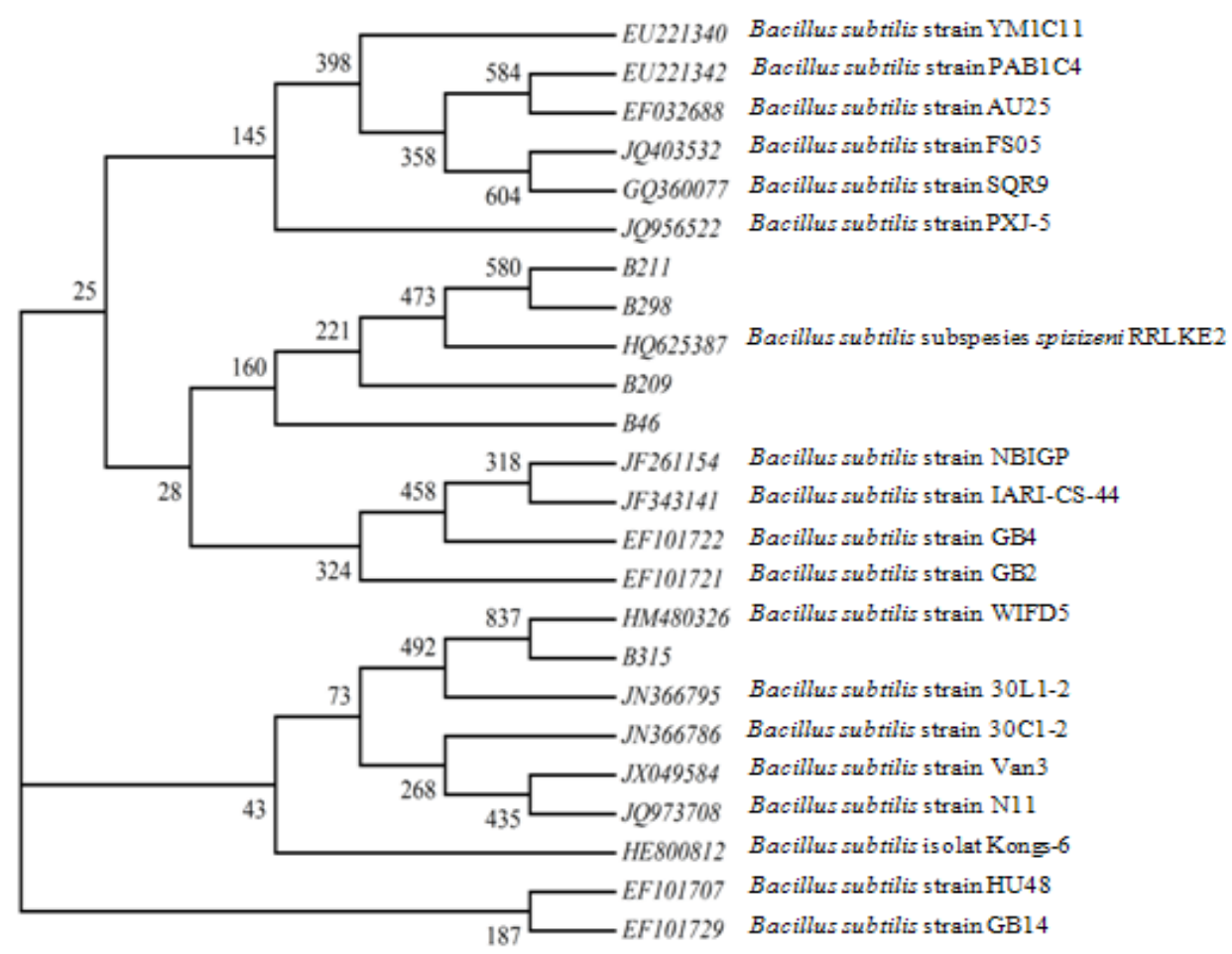

Figure 3. Phylogenetic tree of five isolates of Bacillus spp. based on the partial sequence of the 16S rRNA gene

Four isolates of Bacillus spp. from potato rhizosphere (B46, B209, B211, B298) were the same strains with very similar physiological and biochemical characters except for the B315 isolate. Same strains of Bacillus might have the same potential.

All of Bacillus sp. isolated from potato rhizosphere have $98 \%$ similarity with $B$. subtilis, and the results of the phylogenetic tree construction showed that Bacillus sp. B46, B209, B211, and B298 have similarity with B. subtilis subsp. spizizeni RRLKE2. Bacillus sp. B315 was similar to B. subtilis strain WIFD5. Microencapsulate formula of five isolates as liquid and dry biopesticides needs to be studied. B. subtilis B298 was potential as biocontrol agents for anthracnose disease in chili with the shelf-life of 5 weeks in microencapsulate formula (Prihatiningsih et al. 2019; 2020).

It can be concluded that five isolates of rhizobacteria from potato Granola varieties have the same physiological and biochemical characters as Bacillus sp. Four isolates (B46, B209, B211, and B298) were homologous with $B$. subtilis subsp. spizizeni RRLKE2 and one isolate $(B$. subtilis B315) homologous with B. subtilis strain WIFD5. All isolates inhibit the growth of $R$. solanacearum by antibiosis and bacteriostatic mechanisms. Five isolates of Bacillus spp. from potato rhizosphere are potential as a biopesticide.

\section{ACKNOWLEDGEMENTS}

This research was conducted with full funding from the Directorate General of Higher Education of the Republic of
Indonesia through the BPPS scholarship and there are no potential conflicts of interest.

\section{REFERENCES}

Abusham RA, Rahman RNZRA, Salleh AB, Basri M. 2009. Optimization of physical factors affecting the production of thermo-stable organic solvent-tolerant protease from a newly isolated halo tolerant Bacillus subtilis strain Rand. Microbial Cell Factories Microb Cell Fact 8: 20. DOI: 10.1186/1475-2859-8-20.

Amin A, Khan MA, Ehsanullah M, Haroon U, Azam SMF, Hameed A. 2012. Production of peptide antibiotics by Bacillus sp. GU 057 indigenously isolated from saline soil. Braz J Microbiol 43 (4): 13401346. DOI: 10.1590/S1517-838220120004000015

Ashiru AW, Teniola OD, Dibiana NN, Apena A. 2012. Isolation of starch degrading spoilage bacteria from 'Ogi' (fermenting maize starch). Pak J Nutr 11 (3): 243-246. DOI: 10.3923/pjn.2012.243.246

Calvo P, Ormeño-Orrillo E, Martínez-Romero E, ZúñigaI D. 2010. Characterization of Bacillus isolates of potato rhizosphere from andean soils of Peru and their potential PGPR characteristics. Braz J Microbiol 41: 899-906. DOI: 10.1590/S1517-83822010000400008

Chun W, Vidaver AK. 2001. Gram-Positive Bacteria: Bacillus. In: Schaad NW, Jones JB, Chun W (Eds.). Plant Pathogenic Bacteria $3^{\text {nd }}$ ed. APS Press, St. Paul Minnesota.

Fahy PC, Hayward AC. 1983. Media and Methods for Isolation and Diagnostic Test. In: Fahy PC, Persley GJ (Eds.) Plant Bacterial Diseases A Diagnostic Guide. Academic Press, London.

Ghosh S, Sinha A, Sahu C. 2007. Isolation of putative probionts from the intestines of Indian major carps. Israel J Aquaculture-Bamigdeh 59 (3): $127-132$

Goto M. 1992. Fundamentals of Bacterial Plant Pathology. Academic Press, New York.

Irfan M, Nadeem M, Syed QA, Baig S. 2011. Production of thermostable $\alpha$-amylase from Bacillus sp. in solid-state fermentation. J Appl Sci Res 7 (5): 607-617. 
Jamil B, Hasan F, Hameed A, Ahmed S. 2007. Isolation of Bacillus subtilis MH-4 from soil and its potential of polypeptidic antibiotic production. Pak J Pharm Sci 20 (1): 26-31.

Khan JA, Priya R. 2011. A Study on partial purification and characterization of extracellular amylases from Bacillus subtilis. Adv Appl Sci Res 2 (3): 509-519.

Kohl J, Kolnaar R, Ravensberg WJ. 2019. Mode of action of microbial biological control agents against plant diseases: Relevance beyond efficacy. Front Plant Sci 10: 845. DOI: 10.3389/fpls.2019.00845

Lelliot RA, Stead DE. 1987. Methods for The Diagnosis of Bacterial Diseases of Plant. British Society for Plant Pathology by Blackwell Scientific Publication, Melbourne.

Lenteren JC, Bolckmans K, Köhl J. 2018. Biological control using invertebrates and microorganisms: Plenty of new opportunities. BioControl 63: 39-59. DOI: 10.1007/s10526-017-9801-4

Mugiastuti E, Suprayogi, Prihatiningsih N, Soesanto L. 2020. Isolation and characterization of the endophytic bacteria, and their potential as maize disease control. Biodiversitas 21 (5): 1809-1815. DOI: 10.13057/biodiv/d210506

Muthoni J, Shimelis H, Melis R. 2012. Management of bacterial wilt [Rhalstonia solanacearum Yabuuchi et al. 1995] of potatoes: Opportunity for host resistance in Kenya. J Agric Sci 4 (9): 64-78. DOI: $10.5539 /$ jas.v4n9p64

Pandey A, Nigam P, Soccol CR, Soccol VT, Singh D, Mohan R. 2000. Advances in microbial amylases. Biotechnol Appl Biochem 31 (2): 135-152. DOI: 10.1042/ba19990073.

Prihatiningsih N, Soedarmono, Arwiyanto T, Hadisutrisno B. 2006. Pengendalian hayati penyakit layu bakteri kentang dengan Bacillus sp.: Eksplorasi dan pengujian in vitro dan di rumah plastik. Agrosains 8 (1): 27-31. [Indonesian]

Prihatiningsih N, Djatmiko HA, Rochminarsi E. 2011. Application of potassium fertilizer and Bacillus sp. biopesticide for increasing tomato resistance to bacterial wilt disease. Agrivita 33 (1): 8-14.

Prihatiningsih N, Djatmiko HA. 2016. Enzim Amilase sebagai komponen antagonis Bacillus subtilis B315 terhadap Ralstonia solanacearum kentang. Jurnal Hama dan Penyakit Tumbuhan Tropika 16 (1): 10-16. [Indonesian]

Prihatiningsih N, Djatmiko HA, Erminawati. 2019. Bio-management of anthracnose disease in chilli with microencapsulates containing
Bacillus subtilis B298. IOP Conf Ser Earth Environ Sci 250: 012041. DOI: 10.1088/1755-1315/250/1/012041

Prihatiningsih N, Erminawati, Djatmiko HA. 2020. Shelf-life of Bacillus subtilis B298 inclusion in biopesticide microencapsule formula and its efficacy in suppressing anthracnose disease on chili. IOP Conf Ser Earth Environ Sci 468: 012027. DOI: 10.1088/17551315/468/1/012027.

Sands DC. 1990. Physiological Criteria-Determinative Test. In: Klement Z, Rudolph K, Sands DC (eds.). Methods in Phytobacteriology. Academiai Kiado, Budapest.

Schaad NW. 2001. Initial Identification of Common Genera. In: Schaad NW, Jones JB, Chun W (Eds.) Laboratory Guide for Identification of Plant Pathogenic Bacteria. APS Press, St. Paul. Minnesota

Sharma S, Kaur M. 2010. Antimicrobial activities of rhizobacterial strains of Pseudomonas and Bacillus strain isolated from rhizosphere soil of carnation (Dianthus caryophyllus cv. Sunrise). Indian J Microbiol 50 (2): 229-232. DOI: 10.1007/s12088-010-0045-6.

Singh D, Yadav DK, Chaudhary G, Rana VS, Sharma RK. 2016. Potential of Bacillus amyloliquefaciens for biocontrol of bacterial wilt of tomato incited by Ralstonia solanacearum. J Plant Pathol Microbiol 7: 327. DOI:10.4172/2157-7471.1000327.

Slepecky RA, Hemphill HE. 1992. The Genus Bacillus-Nonmedical. In: Balows A, Truper HG, Dworkin M, Harder W, Schleifer KH (eds.). The Prokaryotes $2^{\text {nd }}$ ed. A Handbook on the Biology of Bacteria: Ecophysiology, Isolation, Identification, Applications. Springer Verlag, New York.

Slepecky RA, Hemphill HE. 2006. The Genus Bacillus-Nonmedical. In: Balows A, Truper HG, Dworkin M, Harder W, Schleifer KH (eds.). The Prokaryotes $4^{\text {th }}$ ed. A Handbook on the Biology of Bacteria: Ecophysiology, Isolation, Identification, Applications. Springer Verlag, New York.

Yabuuchi E, Kosako Y, Yano L, Hotta H, Nishiuchi Y. 1995. Transfer of two Burkholderia and an Alcaligenes species to Ralstonia gen. nov.: Proposal of Ralstonia pickettii (Ralston, Palleroni, and Doudoroff 1973) comb. nov., Ralstonia solanacearum (Smith 1896) comb. nov. Microbiol Immunol 39: 897-904.

Yanti Y, Hamid H, Reflin, Warnita, Habazar T. 2020. The ability of indigenous Bacillus spp. consortia to control the anthracnose (Colletotrichum capsici) and increase the growth of chili plants. Biodiversitas 21 (1): 197-186. DOI: 10.13057/biodiv/d210123. 